to the flood of protest pouring in on them against this betrayal of the Pueblo Indians for the sake of a few New Mexico land-grabbers.The New York World.

\section{SPECIAL ARTICLES SERIES REGULARITIES IN THE ARC SPECTRUM OF CHROMIUM}

THE detection of two sets of related triplets, by Meggers and Kiess, in the course of their work on the arc spectrum of chromium, induced the present writers to undertake a more thorough examination of the spectrum, to find, if possible, other regularities which might lead to series relationships. While a detailed diseussion of the work has not yet been completed, enough has been found to warrant the following statements.

At least three sets of series whose members are triplets, occur in the are spectrum of chromium. Of these, two sets are composed of wide triplets, and one set of narrow triplets. The wide-triplet series are parallel; that is, there exists a constant difference between the wave numbers of homologous members. Each component of the first member of the diffuse series is itself a narrow triplet. In the table are given data for the first members of the principal, sharp and diffuse series of the two parallel systems: .
The narrow triplets which constitute the third set of series are characterized by the frequency differences $\Delta \nu_{1}=8.80$ and $\Delta v_{2}=5.65$. Several doublets in which each of these separations exists and also one with the separation, $\Delta y=$ 81.37, have likewise been found. These are suggestive of inter-series combinations.

\section{C. Kress}

HaRriet KNudsen Kiess

Washington, D. C.,

Octorer 10, 1922

\section{THE NATIONAL ACADEMY OF SCIENCES}

THE autumn meeting was held in New York City on November 14, 15 and 16, on successive days at Columbia University, the Rockefeller Institute for Medical Research and the United Engineering Societies Building. The scientific program was as follows:

Biographical memoir of Harmon Northrup Morse. (By title) IrA ReMsen.

A catalogue of bright stars, a compilation of all the known data concerning the 9110 brightest stars: FranK SCHLESINGER. The requirements for an abstract are perhaps sufficiently complied with by the title itself, but it may be well to say in addition that the catalogue gives the name of each star, its position for 1900, the Durchmusterung number, magnitude, spectrum, proper mo-

\begin{tabular}{|c|c|c|c|c|c|c|}
\hline $\begin{array}{l}\lambda \text { I. A. } \\
\text { (Vacuum) }\end{array}$ & $v$ & $\Delta \nu$ & $\begin{array}{c}\lambda \text { I. A. } \\
\text { (Vacuum) }\end{array}$ & $v$ & $\Delta v$ & Separation \\
\hline $\begin{array}{c}p \\
4255.53 \\
4275.99 \\
4290.92\end{array}$ & $\begin{array}{l}23498.84 \\
23386.40 \\
23305.02\end{array}$ & $\begin{array}{r}112.44 \\
81.38\end{array}$ & $\begin{array}{c}p \\
3579.69 \\
3594.50 \\
3606.35\end{array}$ & $\begin{array}{l}27935.38 \\
27820.28 \\
27728.86\end{array}$ & $\begin{array}{r}115.10 \\
91.42\end{array}$ & $\begin{array}{c}4436.54 \\
4433.88 \\
4423.84\end{array}$ \\
\hline $\begin{array}{c}s \\
7464.39 \\
7402.26 \\
7357.95\end{array}$ & $\begin{array}{l}13396.94 \\
13509.39 \\
13590.74\end{array}$ & $\begin{array}{r}112.45 \\
81.35\end{array}$ & $\begin{array}{c}s \\
11160.2 \\
11018.6 \\
10908.8\end{array}$ & $\begin{array}{l}8960.4 \\
9075.6 \\
9166.9\end{array}$ & $\begin{array}{r}115.2 \\
91.3\end{array}$ & $\begin{array}{l}4436.5 \\
4433.8 \\
4423.8\end{array}$ \\
\hline $\begin{array}{c}d \\
5331.18 \\
5330.58 \\
5329.80\end{array}$ & $\begin{array}{l}18757.57 \\
18759.68 \\
18762.43\end{array}$ & 112.78 & $\begin{array}{c}d \\
6982.79 \\
6981.75 \\
6980.23\end{array}$ & $\begin{array}{l}14320.92 \\
14323.06 \\
14326.18\end{array}$ & 115.16 & $\begin{array}{l}4436.65 \\
4436.62 \\
4436.25\end{array}$ \\
\hline $\begin{array}{l}5299.32 \\
5298.81\end{array}$ & $\begin{array}{r}18870.35 \\
18872.16\end{array}$ & & $\begin{array}{l}6927.90 \\
6927.09 \\
6925.96\end{array}$ & $\begin{array}{l}14434.39 \\
14436.08 \\
14438.43\end{array}$ & & $\begin{array}{l}4434.27 \\
4433.73\end{array}$ \\
\hline $\begin{array}{l}5277.56 \\
5277.09 \\
5276.59\end{array}$ & $\begin{array}{l}18948.15 \\
18949.84 \\
18951.64\end{array}$ & 81.29 & $\begin{array}{l}6885.00 \\
6884.23 \\
6883.40\end{array}$ & $\begin{array}{l}14524.33 \\
14525.96 \\
14527.62\end{array}$ & 91.54 & $\begin{array}{l}4423.82 \\
4423.88 \\
4424.02\end{array}$ \\
\hline
\end{tabular}

